\title{
POLYCULTURAL COMPETENCE CLUSTERS IN HIGHER EDUCATION: CREATINGAN OUTCOMES-BASED COMPETENCE PROFILE
}

\author{
S.L. Suvorova, alex97@shadrinsk.net, \\ T.V. Khilchenko, tkhill@rambler.ru \\ Shadrinsk State Pedagogical University, Shadrinsk, Russian Federation
}

\begin{abstract}
Nowadays clusters are recognized as an important instrument for promoting industrial development, innovation, competitiveness and growth. Although primarily driven by the efforts made by private companies and individuals, clusters are influenced by governments and other public institutions at national and regional levels.

An educational cluster is a set of interrelated vocational education institutions of various levels that are united by industry with each other and are connected by partnership with industry enterprises. The principles of the functioning of the educational cluster is a single educational, scientific and innovation process in conjunction with the economy and the social sphere; the continuity of the educational process and the relationship of educational programs at various levels; organizational, educational and methodical, scientific and informational interaction between all subjects of the cluster.

This article attempts to develop and describe a cluster of polycultural competences of university students by means of creating an applied profile of competences. The purpose of this study is to describe polycultural competences and to define the profile of applied competences in form of a cluster of polycultural competencies (PCC). The authors consider clusters of polycultural competences as an integral part of the educational campus within the concept framework of Shadrinsk State Pedagogical University.

To determine the essence of the concept of a cluster of polycultural competences, theoretical, empirical, observational, and diagnostic methods were implemented, such as: a review of scientific literature, a compilation of best practices, observation, statistical methods, etc. As a result, a cluster of polycultural competences was defined as a set of competences.

The authors analyzed the programs of partner universities and organized international webinars and internships for bachelors and masters abroad and developed online courses "foreign language for undergraduate students and masters". Experimental data obtained during the implementation of cluster training show the effectiveness of the formation of students' polycultural competencies.
\end{abstract}

Keywords: polycultural competence clusters, creating an outcomes-based competence profile, the PCC foreign language technology.

\section{Introduction}

The purpose of the paper is to analyze the polycultural competence clusters (PCC) of the European universities and to present a polycultural competence cluster of the Shadrinsk state pedagogical university, namely the PCC foreign language technology. The authors developed online courses "foreign language for undergraduate students and masters" (https://eos.shspu.ru/) on the platform of MOODLE learning environment which can be easily integrated into classroom activities. The purpose of the courses is to implement such effective learning methods as intensive practice through tasks, real-life lesson models and situations, cross-cultural interaction training, research projects, group discussions, interactive tasks for the development of students' polycultural competences. The developed courses were successfully implemented in the educational process. The results of placement and final tests show a significant improvement in the development of students' professional competences.

\section{Literature review}

Educational clusters and new technologies in the polycultural education highlight the importance of generating qualified human resources. Their contribution to the creation of outcomesbased competence profiles is the subject of research of both Russian and foreign scientists such as S.S. Espaev [7], G.F. McAllister, J.J. Irwing [15], A.V. Torkhova [23] and others. Based on specific characteristics of economic clusters de- 


\section{Теория и методика профессионального образования}

fined by Porter A. Makulova, G. Alimzhanova, Z. Bekturganova, Z. Umirzakova, L. Makulova, K. Karymbayeva [14] study the competence based approach in education and define the model of professional competence. Competence model of the graduate must guarantee getting a qualification corresponding to his future career. It is expected that competences acquired by the student in high school, will manifest themselves in different everyday life and professional situations.

The model of educational cluster developed by the scientist E.I. Sokolova [19] is of great importance for our research. The essence of the concept of educational clusters is to unite the leading industrial university institutions and primary and secondary vocational educational institutions, specialized schools, basic enterprises, main customers and consumer specialists.

Modeling polycultural competence clusters (PCC) is based on research carried out by A. Galante [8], J. Diller, J. Moule [6], D.W. Sue, P. Arrendondo, R.J. McDavis [20]. Based on the above mentioned research the essence of the concept "polycultural competence of the personality" can be defined as polycultural tolerance and sociocultural identity.

\section{Methodology}

Competence is an integrated concept that indicates the ability of the individual to use independently various elements of knowledge, skills and attitudes in everyday and new situations $[1,6,8]$. Polycultural competence is considered as the combination of cultural tolerance and sociocultural identity. Polycultural competence is also viewed as an integrative quality that is reflected in a person's awareness of the content and means of interaction with the polycultural world and realized in a person's ability to function in a polycultural world $[12,25]$.

A cluster of educational competences as a planned result of polycultural education is currently being formed under the influence of interaction, though formalized, appropriate structures and labour market segments [7, pp. 159-162].

We can list some key points and strategies that should be the basis of the polycultural competence formation:

"Lifelong learning".

This approach presupposes the creation of conditions for formation the competencies at the university and then in the profession.

Student-centered approach.

This approach means taking into account the priority of interests, desires, motivations of students to participate in educational programs.

Practice-oriented approach (work-based learning).

This approach means the development of the scientific and innovative potential of students and the formation of their linguistic and cultural competences.

The approach of "open education".

This approach is aimed at providing open access for students to recognized foreign knowledge centers.

We used such methods:

Theoretical methods: a) analysis of normative documents on education was used to justify the urgency of the problem and determine the legal possibilities for its solution - creating an outcomes-based competence profile; b) the theoretical and methodological analysis allowed to formulate the key initial positions of the research the position of polycultural competence clusters (PCC) in higher education; c) system analysis was the basis for a holistic review of the problem; d) forecasting and long-term planning was used to identify and analyze the factors that caused the emergence of the problem under study, justification of the possibility of its solution - polycultural competence clusters (PCC) in higher education as a variant of the result of outcomesbased competence profile.

Empirical methods: a) generalization and analysis of effective international experience and practice of domestic and foreign higher schools in the creation of clusters of competences aimed the creating an outcomes-based competence profile; b) the focus group method was used to elucidate students' attitudes towards the formation of polycultural competences in the cluster.

Observation methods: observation (direct, indirect) was used to determine the potential of students to participate in the program of forming competences in foreign languages - the developing online courses "foreign language for undergraduate students and masters".

Diagnostic methods: questioning, interviewing, conversation, testing, self-assessment, expert assessments were used to determine the level of the formation of linguistic, polycultural and professional competences of students for creating of polycultural competence clusters (PCC) in higher education.

\section{Results}

The PCC foreign language technology is focused on the evaluation and transfer of promising 
new technologies and methods tothe broad field of multicultural communication andforeign languagebusiness communication. Polycultural competence cluster contains such competences as communicative, cultural, intercultural, sociocultural and such components as the objectives component, the content component, the operational component and the evaluation-resultative component [2-4].

Various innovative methods of teaching are necessary for the students' polycultural competences development. The authors offer such methods as microteaching, method of group dynamics, methods of training and consulting.

Microteaching is the art of teaching, a complex process, which is not limited to transferring of knowledge from one to another. Microteaching is a special teaching practice model or teaching training method. In this teaching context, there are many actions like the use of methods, the usage of media, learning guide, motivation, classroom management, assessment, analyzing and so on.

The concept of microteaching is mainly based on the following points [9, pp. 124-128]:

- Teaching in its real form but with a minimum concept.

- The exercise which is designed focuses mostly on the basic teaching skills with the help of feedback based on the knowledge and information of student learning level.

- The teaching is conducted for students who are from different cultural backgrounds.

- Monitoring the micro teaching exercises conducted in classrooms.

- Enabling the prospective teachers to learn effective teaching skills.

- Helping the students to actively participate in teaching by providing low risk situation.

- It also offers opportunities for retraining at regular time intervals.

Method of group dynamics. Group dynamics deals with the attitudes and behavioral patterns of a group. Group dynamics concern how groups are formed, what is their structure and which processes are followed in their functioning. Thus, it is concerned with the interactions and forces operating between groups. We used the method of group dynamics in the formation of students' language competences at the Faculty of $\mathrm{Hu}-$ manities.

Methods of training and consulting. Pedagogical consulting is a consultative structuring, related to educational support of developmental learning processes, as well as activities that allow an independent expert evaluation of the effectiveness of the use of teaching technologies.

In our study, pedagogical consulting is positioned as the activity of a teacher (consultant), aimed at assisting the student in finding a solution to his problem situation related to the study of a different language and linguoculture [10, pp. 1350-1352].

In the mainstream of our research, we identified three types of pedagogical consulting: problem-oriented, aimed at analyzing the essence and external causes of linguistic intercultural problems, and searching for ways to resolve them; Person-centered, centered on the analysis of individual causes of the problem; decision-oriented, centered on identifying resources to solve identified problems.

In order to encourage elementary students to start speaking and provide them with some thoughtprovoking material we have developed a Moodle online practice course, some parts of which are used by students outside the classroom, but some exercises are really good additional practice to work in class [5]. The course consists of nine lessons (units) and extra practice activities. Everything that students learn in the online course is discussed in class. The aim of the online course is to provide students with exciting practice material full of clear and meaningful ideas that cannot leave students indifferent and encourage them to speak using their emotions and experience. Thus, we can say that the online course is designed to help students develop their speaking skills that we use to teach students the other skills and explain the material of the lessons $[1,2,11]$. This two-way process helps students gain nearnative competence in the language step by step.

Formation of polycultural competences in the learning process and their evaluation greatly facilitates the description of competences or their clusters in the form of observable signs of manifestation (descriptors or indicators). Such descriptions are useful for three reasons [24, pp. 20-22; 14, pp. 183-192]. First, they provide practical guidelines for the work of teachers in the formation of competencies, since they are usually of a pragmatic nature and link the conceptual formulations of competences with target indicators in the form of real skills to implement practice-oriented and professionally-oriented actions (labor functions) that should be formed by a student. Secondly, these descriptions are necessary in the work of the authors of tasks in the de- 


\section{Теория и методика профессионального образования}

velopment of funds of competence-oriented assessment tools. Thirdly, they are necessary for experts when assessing the results of students' performance in the competence formation process [13].

\section{Conclusions}

Competence model of the graduate must guarantee getting a qualification corresponding to his future career $[15,16,18]$. It is expected that competences acquired by the student in high school, will manifest themselves in different everyday-life and professional situations.

In this case, there are two groups of competences: versatile (universal, over objective) and specific (objective-specific, objective-specialized). Flexibility to move from competences into new types of activities, which manifests itself in the ability to use the existing knowledge and experience in new conditions and less rigid attachment to the objects and labor tools, is one of their main characteristics.

Special competences reflect the professional qualification [17, pp. 10-13]. They differ for different disciplines (directions, special training). Despite the existence of two types of competences, the description of both versatile and specific competences is possible only with a sufficiently high degree of generalization and "transpersonal" nature of their content.

Competency-based model of a specialist is not a model of a graduate, because competency is inextricably linked with the experience of a successful activity, which the student can acquire in the proper amount during the course of training in the university. Therefore, in the development of the competency-based model of the graduate, as the goal of higher education we should reduce the competency-based model of the specialist, beforehand reducing the requirements that are related to professional experience.

On the other hand, it is necessary in the educational program to increase all learning activities (various educational practices, project works, teaching and research work of students, business, role-playing, simulation games, etc.). Competency-based approach, as we can say - is an association of the interests of the employer's, the graduate, the teachers and professionals in order to realize the professional activities in the best way. Therefore, in order to assess the current existing requirements of professional competence in high school, we should be guided by the views of employers [20-22].

Clustering of competences is an extremely necessary work, which should be carried out in two ways: first, experts work, and then the factor analysis device in the approbation process to measure the students' level of competence development.

Thus, the cluster of competences is a set of closely related competencies, united according to certain criteria. Inside clusters, hierarchical levels can be distinguished, or simply lists of competences $[19$, p. $153 ; 23$, p. 517]. The connection between clusters, taking into account their hierarchy, is accomplished by constructing structurally-descriptive models. Modeling is used to identify the main factors of success in the process of forming competences for a specific OT or training direction, so the relationship between clusters, as well as the hierarchy between them and within them, is specific.

Thus, it is possible to formulate a certain sequence of actions for constructing a competence model for training a specialist for a particular vocational training or training direction:

- supplement the tasks of professional activity by developing a part of the tasks taking into account the specifics of the region in which the university is located and the profile orientation of the OP for the preparation of a bachelor's or master's degree;

- to develop a set of professional-specialized competencies for the OP taking into account its profile orientation and to combine them with the professional competencies of the GEF in the relevant area of training;

- structuring competences on clusters;

- to introduce a hierarchy into a set of competence clusters (professional and professionallyspecialized) for the OP taking into account its profile orientation;

- to build a competence model for the bachelor's (master's) degree training.

\section{Acknowledgements}

This research has been funded by the FS source on the topic "Cluster model of multilingual training of university students" (No. 34H from 22.01.2019).

\section{References}

1. Albino G. Improving Speaking Fluency in a Task-Based Language Teaching Approach: The Case of EFL Learners at PUNIV-Cazenda. Sage open, 2017, vol. 7, iss. 2, pp. 233-238. DOI: $10.1177 / 2158244017691077$

2. Amir H.A. An Investigation Into the Benefits of the Intercultural Approach to EFL 
Learning and Teaching: A Case Study of Taif University, KSA. Journal of Language Teaching and Research, 2017, vol. 8, no. 1, pp. 52-63. DOI: $10.17507 / \mathrm{jltr} .0801 .07$

3. Barnes M.E. Encouraging Interaction and Striving for Reciprocity: The Challenges of Community-Engaged Projects in Teacher Education. Teaching and Teacher Education, 2017, vol. 68, pp. 220-231. DOI: 10.1016/j.tate.2017.09.004

4. Borg S. The Distinctive Characteristics of Foreign Language Teachers. Language Teaching Research, 2006, vol. 10, iss. 1, pp. 3-31. DOI: 10.1191/1362168806Ir182oa

5. Cheng X. Model Study of English Listening and Speaking Mobile Learning Based on Podcasting. Agro Food Industry Hi-Tech, 2017, vol. 28, iss. 3, pp. 3085-3087.

6. Diller J., Moule J. Cultural Competence: A primer for Educators. Belmont, CA: Thomson Wadsworth, 2005, pp. 91-97.

7. Espaev S.S. [Educational Cluster - the Key to Personnel Competitiveness in Kazakhstan]. Global'nye vyzovy i sovremennye trendy razvitiya vysshego obrazovaniya: Mezhdunarodnaya nauchno-prakticheskaya konferentsiya, posvyashchennaya 50-letiyu Kazakhskogo ekonomicheskogo universiteta imeni T. Ryskulova: sb. tezisov 4-5 oktyabrya $2013 \mathrm{~g}$. [Global Challenges and Modern Trends in the Development of Higher Education: International Scientific and Practical Conference Dedicated to the 50th Anniversary of the T. Ryskulov Kazakh Economic University: Coll. Abstracts October 4-5]. Almaty, 2013, pp. 159-162. (in Russ.)

8. Galante A. Intercultural Communicative Competence in English Language Teaching: Towards Validation of Student Identity. BELT Journal, 2015, no. 6(1), pp. 29-39. DOI: 10.15448/2178-3640.2015.1.20188

9. Hastjarjo S., Nuryana A. Intercultural Communication Training in Vocational and Industrial Education Training. IOP Conference Series: Materials Science and Engineering IOP Conference Series: Materials Science and Engineering, 2018, vol. 306, pp. 124-128. DOI: 10.1088/1757-899x/306/1/012115

10. Karbisheva K.S., Nikonova E.D., Kobzeva N.A. [Teaching Foreign Languages on the Basis of an Intercultural Approach]. Young Scientist, 2015, no. 11, pp. 1350-1352. (in Russ.)

11. Kong M.L.F. On Teaching Methods: the Personal Experiences of Teachers of English. RELC Journal, 2017, vol. 48, iss. 2, pp. 197-209. DOI: $10.1177 / 0033688216661251$

12. Kontseptsiya akademicheskoy mobil'nosti $v$ Rossiyskoy Federatsii [The Concept of Academic Mobility Development in the Russian Federation]. Available at: http:// intpr.ntf.ru/DswMedia/ koncepciyaakademicheskoymobilnosti_itog.pdf (accessed 10.12.18).

13. Lai T.-L., Hsieh M.-Y. The Analysis of the Relationship Between Cultural Factor and Second Language Acquisition. Proceedings of the IEEE International Conference on Advanced Materials for Science and Engineering: Innovation, Science and Engineering, IEEE-ICAMSE, 2016, pp. 412-415. DOI: 10.1109/ICAMSE. 2016.7840364

14. Makulova A.T., Alimzhanova G.M., Bekturganova Z.M., Umirzakova Z.A., Karymbayeva K.M. Theory and Practice of CompetencyBased Approach in Education. International Education Studies, 2015, vol. 8, no. 8, pp. 183-192. DOI: 10.5539 /ies.v8n8p183

15. McAllister G.F., Irwing J.J. CrossCultural Competency and Multicultural Teacher Education. Review of Educational Research, 2000, no. $70(1), \quad$ pp. 122-125. DOI: 10.3102/00346543070001003

16. Mansilla V.B., Jackson A. Obuchenie dlya global'noi kompetentsii: Podgotovka molodezhi $k$ mirovomu uchastiyu. Sovet Gosudarstvennukh shkol'nukh chinovnikov po initsiative EdSteps i Partnerstva Aziatskogo obshchestva po global'nomu obucheniyu [Educating for Global Competence: Preparing Our Youth to Engage the World. Council of Chief State School Officers' EdSteps Initiative and Asia Society Partnership for Global Learning]. Available at: http://www.ccsso.org/Resources/Publications/Ed ucating_for_Global_Competence.html (accessed 22.12.2018).

17. Mickenbecker-Soubai B. Interkulturelles Lernen. Frühes Deutsch, 2004, no. 1, pp. 10-13.

18. Proekt povysheniya konkurentosposobnosti vedushchikh rossiyskikh universitetov sredi vedushchikh mirovykh nauchno-obrazovatel'nykh tsentrov. Ministerstvo obrazovaniya i nauki Rossiyskoy Federatsii [The Project to Increase the Competitiveness of Leading Russian Universities Among the World's Leading Research and Educational Centers. Ministry of Education and Science of the Russian Federation]. Available at: http://5top100.ru/about/more-about/ (accessed 15.12.2018).

19. Sokolova E.I. [The term "Educational Cluster" in the Conceptual Field of Modern Pedagogy]. Continuing Education: XXI Century, 2014, no. 2 (6), pp. 153-160. (in Russ.)

20. Sue D.W., Arrendondo P., McDavis R.J. 


\title{
Теория и методика профессионального образования
}

Multicultural Counseling Competencies and Standards: A call for the Profession. Journal of Counseling and Development, 1992, vol. 70, no. 4, pp. 477-486. DOI: $10.1002 / \mathrm{j} .1556-$ 6676.1992.tb01642.x

21. Suvorova S. Functional Map of a Profession: Problems of Modeling. Modern European Researches, 2016, no. 4, pp. 129-135.

22. Suvorova S., Osipova I. Applied Competence Clusters (ACC) in Higher Education: Modeling of Outcomes-Based Competence Profile. ICERI2018 Proceedings, 2018, pp. 8996-8999. DOI: 10.21125 / iceri.2018.0659

23. Torkhova A.V. [Prospects for Cluster Development of the System of Pedagogical Education of the Republic of Belarus]. XI Mezduna- rodnaya nauchno-prakticheskaya konferentsiya "Psikhologiya lichnostnogo i professional'nogo razvitiya sub" "ektov nepreryvnogo obrazovaniya" [XI International Scientific and Practical Conference "Psychology of Personal and Professional Development of Subjects of Continuous Education”]. 2015, pp. 517-520. (in Russ.)

24. Villegas A.M., Lucas T. Preparing Culturally Responsive Teachers: Rethinking the Curriculum. Journal of Teacher Education, 2002, no. $3(1)$, pp. 20-22. DOI: $10.1177 / 0022487102053001003$

25. Yang R. University Internationalization: Its Meanings, Rationales and Implications. In Intercultural Education, 2002, no. 13 (1), pp. 89-95.

Received 20 February 2019

\section{КЛАСТЕРЫ ПОЛИКУЛЬТУРНЫХ КОМПЕТЕНЦИЙ В СИСТЕМЕ ВЫСШЕГО ОБРАЗОВАНИЯ: СОЗДАНИЕ ОРИЕНТИРОВАННОГО НА РЕЗУЛЬТАТ ПРОФИЛЯ}

\author{
С.Л. Суворова, Т.В. Хильченко \\ Шадринский государственный педагогический университет, г. Шадринск, Россия
}

На современном этапе кластеры признаются в качестве важного инструмента, способствующего промышленному развитию, инновациям, конкуренции и общественному развитию. Хотя первоначально кластеры продвигались усилиями частных компаний и частного сектора, сейчас на их формирование влияют правительства и другие общественные организации на национальном и региональном уровнях.

Образовательный кластер представляет собой совокупность взаимосвязанных учреждений профессионального образования разного уровня, которые объединены и связаны партнерскими отношениями с промышленными предприятиями. Принципы функционирования образовательного кластера - это слияние образовательного, научного и инновационного процессов и взаимосвязи образовательных программ различных уровней; организационное, учебно-методическое, научное и информационное взаимодействие между всеми субъектами кластера. Кроме того, кластер рассматривается и как комплексная модель какого-либо объекта.

В статье предпринята попытка создания и описания кластера поликультурных компетенций студентов университета посредством описания прикладных компетенций профиля. Цель исследования - поиск эффективных способов описания кластера и формирования поликультурных компетенций студентов университета, одним из которых является создание ориентированного на результат профиля данных компетенций. Авторы рассматривают кластеры поликультурных компетенций в качестве необходимого компонента образовательного кампуса концепции ШГПУ.

Чтобы определить суть кластера поликультурных компетенций, были использованы теоретические, эмпирические методы, а также методы наблюдения и диагностики: обзор научной литературы, компиляция положительного опыта, наблюдение, статистическая обработка и т. д. В результате, кластер поликультурных компетенций был определен как набор компетенций, формирование которых обеспечивается путем кластерного обучения. 
Авторами проанализированы программы вузов-партнеров и проведены вебинары и обучение в интернатуре для студентов, обучающихся по программам бакалавриата и магистратуры за границей, а также разработаны онлайн-курсы «Иностранный язык для бакалавров и магистров». Экспериментальные данные, полученные в ходе внедрения кластерного обучения, показывают эффективность формирования поликультурных компетенций студентов.

Ключевые слова: кластеры поликультурных компетенций; создание ориентированного на результат профиля; технология формирования кластеров поликультурных компетенций в иностранном языке.

\section{Лumepamypa}

1. Albino, G. Improving speaking fluency in a task-based Language Teaching Approach: The Case of EFL Learners at PUNIV-Cazenda / G. Albino // Sage open. - 2017. - Vol. 7. -Iss. 2. - P. 233-238.

2. Amir, H.A. An Investigation into the Benefits of the Intercultural Approach to EFL Learning and Teaching: A Case Study of Taif University, KSA / H.A. Amir // Journal of Language Teaching and Research. - 2017. - Vol. 8, no. 1. - P. 52-63.

3. Barnes, M.E. Encouraging interaction and striving for reciprocity: The challenges of communityengaged projects in teacher education / M.E. Barnes // Teaching and Teacher Education. - 2017. Vol. 68. - P. 220-231.

4. Borg, S. The distinctive characteristics of foreign language teachers / S. Borg // Language Teaching Research. - 2006. - Vol. 10. - Iss. 1. - P. 3-31.

5. Cheng, X. Model study of English listening and speaking mobile learning based on podcasting / X. Cheng // Agro Food Industry Hi-Tech. - 2017. - Vol. 28. - Iss. 3. - P. 3085-3087.

6. Diller, J. Cultural competence: A primer for educators / J. Diller, J. Moule // Belmont, CA: Thomson Wadsworth. - 2005. - P. 91-97.

7. Еспаев, С.С. Образовательный кластер - залог конкурентоспобности кадров в Казахстане / С.С. Еспаев // Глобальные вызовы и современные тренды развития высшего образования: Международная научно-практическая конференция, посвященная 50-летию Казахского экономического университета имени Т. Рыскулова: сб. тезисов 4-5 окт. 2013 г. - Алматы, 2013. C. $159-162$.

8. Galante, A. Intercultural communicative competence in English language teaching: towards validation of student identity / A. Galante // BELT journal. - 2015. - No. 6(1). - P. 29-39.

9. Hastjarjo,S. Intercultural Communication Training in Vocational and Industrial Education Training / S.Hastjarjo, A. Nuryana // IOP Conference Series: Materials Science and Engineering IOP Conference Series: Materials Science and Engineering. - 2018. - Vol. 306. - P. 124-128.

10. Карбымева, К.С. Обучение иностранным языкам на базе межкультурного подхода / К.С. Карбышева, Е.Д. Никонова, Н.А. Кобзева // Молодой ученый. - 2015. - № 11. - С. 1350-1352.

11. Kong, M.L.F. On teaching methods: the personal experiences of teachers of English / M.L.F. Kong // RELC Journal. - 2017. - Vol. 48. - Iss. 2. - P. 197-209.

12. Конщепџия академической мобильности в Российской Федераџии. - http://intpr.ntf.ru/ DswMedia/koncepciyaakademicheskoymobilnosti_itog.pdf (дата обращения: 10.12.2018).

13. Lai, T.-L.The Analysis of the Relationship Between Cultural Factor and Second Language Acquisition / T.-L. Lai, M.-Y. Hsieh // Proceedings of the IEEE International conference on advanced materials for science and engineering: innovation, science and engineering . -2016. - P. 412-415.

14. Theory and practice of competency-based approach in education / A.T. Makulova, G.M. Alimzhanova, Z.M. Bekturganova et al. // Education Studies. - 2015. - Vol. 8. - No. 8. - P. 183-192.

15. McAllister, G.F. Cross-Cultural competency and multicultural teacher education / G.F. McAllister, J.J. Irwing // Review of Educational Research. - 2000. - No. 70 (1). - P. 122-125.

16. Mansilla, V.B. Educating for global competence: preparing our youth to engage the world. Council of Chief State School Officers' EdSteps Initiative and Asia Society Partnership for Global Learning / V.B. Mansilla, A. Jackson. -http://www.ccsso.org/Resources/Publications/Educating_for_ Global_Competence.html (дата обращения: 22.12.2018).

17. Mickenbecker-Soubai, B. Interkulturelles Lernen / B. Mickenbecker-Soubai // Frühes Deutsch. 2004. - No. 1. - P. 10-13. 


\section{Теория и методика профессионального образования}

18. Проект повышения конкурентоспособности ведущих российских университетов среди ведущих научно-образовательных иентров. Министерство образования и науки Российской Федерачии. - http://5top100.ru/about/more-about/ (дата обращения: 25.12.2018).

19. Соколова, Е.И. Термин «Образовательный кластер» в понятийном поле современной педагогики / Е.И. Соколова // Непрерывное образование: ХХІ век. - 2014. - № 2 (6). - C. 153-160.

20. Sue, D.W. Multicultural counseling competencies and standards: A call for the profession / D.W. Sue, P. Arrendondo, R.J. McDavis // Journal of Counseling and Development. - 1992. - Vol. 70, no. 4. - P. 477-486.

21. Suvorova, S. Functional map of a profession: problems of modeling / S. Suvorova // Modern European researches. - 2016. - No. 4. - P. 129-135.

22. Suvorova, S. Applied Competence Clusters (ACC) in Higher Education: Modeling of Outcomes-Based Competence Profile / S. Suvorova, I. Osipova // ICERI2018 Proceedings. - 2018. P. 8996-8999.

23. Торхова, А.В. Перспективы кластерного развития системы педагогического образования Республики Беларусь / А.В. Торхова // ХI Международная научно-практическая конференция «Психология личностного и профессионального развития субъектов непрерывного образования», 2015. - C. 517-520.

24. Villegas, A.M. Preparing culturally responsive teachers: rethinking the curriculum / A.M. Villegas, T. Lucas // Journal of Teacher Education. - 2002. - No. 3 (1). - P. 20-22.

25. Yang, $R$. University internationalization: its meanings, rationales and implications / R. Yang // In Intercultural Education. - 2002. - No. 13 (1). - P. 89-95.

Суворова Светлана Леонидовна, доктор педагогических наук, профессор, профессор кафедры теории и практики германских языков, Шадринский государственный педагогический университет, г. Шадринск, alex97@shadrinsk.net.

Хильченко Татьяна Викторовна, кандидат педагогических наук, доцент, доцент кафедры теории и практики германских языков, Шадринский государственный педагогический университет, г. Шадринск, tkhill@rambler.ru.

Поступила в редакцию 20 ревраля 2019 г.

\section{ОБРАЗЕЦ ЦИТИРОВАНИЯ}

Suvorova, S.L. Polycultural Competence Clusters in Higher Education: Creatingan Outcomes-Based Competence Profile / S.L. Suvorova, T.V. Khilchenko // Вестник ЮУрГУ. Серия «Образование. Педагогические науки». - 2019. - T. 11, № 2. - C. 47-54. DOI: $10.14529 /$ ped 190205

\section{FOR CITATION}

Suvorova S.L., Khilchenko T.V. Polycultural Competence Clusters in Higher Education: Creatingan Outcomes-Based Competence Profile. Bulletin of the South Ural State University. Ser. Education. Educational Sciences. 2019, vol. 11, no. 2, pp.47-54. DOI: $10.14529 /$ ped190205 